\title{
Increasing Interest in Mathematical Learning Through Model Application Experiential Learning
}

\author{
Hastuty Musa ${ }^{1}$, Amaluddin $^{2}$, Kasrah $^{3}$ \\ Mathematic Education, \\ University of Muhammadiyah ParePare \\ ParePare, Indonesia \\ ${ }^{1}$ hastuty.rusli@gmail.com \\ ${ }^{2}$ Amaluddin1965@gmail.com
}

\begin{abstract}
This research is a class action (classroom action research), which aims to increase students' interest in learning mathematic through learning model of Experiential Learning.The subjects of the research are the students of IX class at SMP Negeri 13 Parepare of 17 students, it consists of 9 male students and 8 female students. The research consists of four stages in implementation including planning (planning), action (action), observations (observation) and reflection (reflection). The research instruments are observation sheet and questionnaire of interest in learning mathematic. The collecting data through observation techniques and questionnaires is analyzed through descriptive analysis techniques.

The results of this research that can be concluded that the interest in learning mathematic through learning model of experiential learning of students in IX class at SMPN 13 Parepare increased. This shows by: (1) the improvement of average value of student interest in the amount of 3.74 or $75 \%$ in the first cycle to be 4.18 or $84 \%$ in the second cycle.
\end{abstract}

Keywords-Interest in Learning Mathematics, Experiential Learning

\section{INTRODUCTION}

The learning model of experiential learning is a student-centered learning that is active in developing knowledge and skills through direct experience. According to [1] experiential learning is a learning model that able of students to build knowledge and skills through direct experience. Model of experiential learning has advantages and disadvantages. According to [2] the advantages of experiential learning models, such as: The time to learning requires a relatively long time. However, this model also has the advantages of experimental learning in problem solving and the results can feel that learning through experience is more effective and it can achieve the maximum goal.

Based on Slameto ([3]) it prefers the flavor and taste of interesting in a matter or activity, without it told before. The procedure of experimental learning model is divided into four stages namely, concrete experience, reflective observation, abstract conceptualization, and active experimental. It relates to this research, experiential learning model attempted to increase interest in mathematic learning with reference to the main activities such as the relating of associate learning with experience that never experienced before then it explains about

abstract concepts is more concrete. In line with the research conducted by Nur Rahmi Nuhung stated that there is influence learning experiential learning model application of interest in learning mathematic of the students IX class at SMP Negeri 13 Parepare.

Based on previous researchers and observations that have been made, then the problem statement of this research is "whether or not the interest in Learning Mathematic can be improved through the application of Learning Experiential Learning in IX Class at SMPN 13 Parepare?

\section{METHOD}

This research was a classroom action research. This research consists of several cycles and each cycle consists of four stages of implementation [4] it includes: planning, action, observations, reflection. To obtain the necessary data in this research, the instrument used the questionnaire of interest in learning mathematics and student activity of observation sheet. The collecting data is analyzed by using descriptive statistics.

\section{RESULT AND DISCUSSION}

\section{Description of Result of Cycle I}

Description of interest in learning mathematic through the application of learning models of experiential learning that results can be seen in Table1.

Table 1. Statistics of interest in learning mathematics to the students in cycle

\begin{tabular}{lc}
\multicolumn{1}{c}{ Statistics } & Score St \\
\hline Subject & 17 \\
Average score & 3.74 \\
Range & 1.28 \\
Median & 3.64 \\
Standard Deviati & 0.36 \\
Variance & 0.13 \\
The Lowest Scor & 3.16 \\
The Highest Sco] & 4.44 \\
Subject IdealSco & 5.00
\end{tabular}


Table 1 shows that the average score of students' interest in studying mathematics after learning model of experiential learning applied was 3.74 with a standard deviation of 0.36 , the highest score of 4.44 and the lowest score of 3.16 obtained by students in the first cycle of the ideal score probably reached 5.00. If the interest in learning mathematic scores is categorized into five categories of interest learning, then the frequency distribution and percentages in Table 2.

Table 2. The Frequency and Percentage Distribution of Interest in Learning Mathematic to the Students in Cycle I

\begin{tabular}{clcc}
\hline Average score & Category & Frequency & $\begin{array}{c}\text { Percentage } \\
(\%)\end{array}$ \\
\hline $1.00 \leq$ Average $<1.50$ & Very & 0 & 0 \\
1.50 & poor & 0 & 0 \\
$\leq$ Average $<2.50$ & Poor & 5 & 29.4 \\
2.50 & Fair & 12 & 70.6 \\
$\leq$ Average $<3.50$ & Good & 0 & 0 \\
3.50 & Very good & & \\
$\leq$ Average $<4.50$ & & & \\
4.50 & & 17 & \\
$\leq$ Average $<5.00$ & & & \\
\hline Totally & & & \\
\hline
\end{tabular}

Table 2 shows that the frequency and percentage of students' interest in studying mathematics after being given the act of learning through the application of learning models Experiential Learning in the first cycle was obtained 5 people or $29.4 \%$ are in the category of interest is fair, and 12 people or $70.6 \%$ are interest categories good. Based on Table 1 and Table 2 can be concluded that the average of student's interest in learning mathematics was 3.74 or $75 \%$ in good category.

\section{The Description of Results of Cycle II}

The questionnaire results in the second cycle reanalyzed by using the same formula in the first cycle and the results shown in Table 3.

TABLE 3. The statistic of interest in learning mathematics to the students in cycle ii

\begin{tabular}{|l|c|}
\hline \multicolumn{1}{|c|}{ Statistics } & Score Statistics \\
\hline Subject & 17 \\
Average score & 4.18 \\
Range & 0.84 \\
Median & 4.16 \\
Standard Deviation & 0.25 \\
Variance & 0.06 \\
The Lowest Score & 3.76 \\
The Highest Score & 4.6 \\
Ideal Subject Score & 5.00 \\
\hline
\end{tabular}

Table 3 shows that the average score of students' interest in learning mathematics in the second cycle after experiential learning applied learning model was 4.18 with a standard deviation of 0.25 , the highest score was 4.6 and the lowest score was 3.76 obtained by students in the second cycle of score possible deal was 5.00. If the interest in learning mathematic scores is categorized into five categories of interest learning, then the frequency distribution and percentages in Table 4.

Table 4. The Frequency and Percentage Distribution of Interest in Learning Mathematic to the Students in Cycle II

\begin{tabular}{clcc}
\hline Average value & Category & Frequency & $\begin{array}{c}\text { Percentage } \\
(\%)\end{array}$ \\
\hline $1.00 \leq$ Average $<1.50$ & Very & 0 & 0 \\
$1.50 \leq$ Average $<2.50$ & poor & 0 & 0 \\
$2.50 \leq$ Average $<3.50$ & Poor & 0 & 0 \\
$3.50 \leq$ Average $<4.50$ & Fair & 15 & 88.2 \\
$4.50 \leq$ Average $<5.00$ & Good & 2 & 11.8 \\
& Very good & & \\
\hline Totally & & 17 & 100 \\
\hline
\end{tabular}

Table 4 shows that the frequency and percentage interest in mathematics learning after a given action learning model through Experiential Learning in the first cycle was obtained 15 students or $88.2 \%$ were in the good categories, and 2 students or $11.8 \%$ were very good category. The average interest in learning mathematics students was 4.18 or $84 \%$ are in either category.

The Improvement Description of Result Questionnaire Learning Mathematics to the Students in Cycle I and Cycle II

Based on the results of questionnaire analysis of interest in learning mathematics students in the cycle I and cycle II then it obtained then there was an increased interest in learning mathematics students. The increased interest in mathematics learning cycle I to II can be seen in Figure 1.

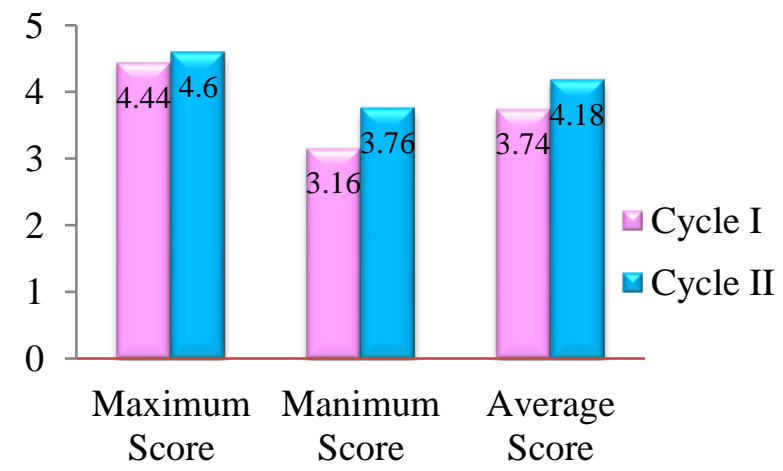

Fig. 1.The Result mathematic of students in the first cycle and the second cycle

Figure 1 can be seen that the maximum score obtained by students increasing from cycle I to cycle II that was from 4.44 to 4.6 and the minimum score obtained by students increased from cycle I to cycle II that was from 3.16 to 3 , 76. Furthermore, the average score increased from the first cycle to the second cycle was 3.74 to 4.18 . Thus, it can be concluded that students' interest in learning mathematic increased from the first cycle to the second cycle after the applying model of experiential learning.

On the result shows that the learning of mathematic in experiential, learning can increase the interest in learning 
mathematic of the students IX class at SMP Negeri 13 Parepare. It refers to the phases of the action research including planning, implementation, observation and reflection; overall, the model of experiential learning has been able to increase interest in studying mathematics at each cycle.

Achievement of interest in learning mathematics from 17 students as research subjects obtained from cycle I showed the result of questionnaire interest in learning mathematics students obtained an average of 3.74 or $75 \%$, after that the interesting in student learning is in the qualification of "good".

As for the needing to improve in the first cycle, such as how the students to be more active in conducting activities in accordance in the learning process and how to minimize students who do some activities that are not in accordance with the learning process. The teachers encourage students and try to control the class well. This is done as Silberman [5] argues that learning as a process whereby knowledge is created through the transformation of experience with the knowledge resulting from the combination of efforts to capture and transform the experiences.

Cycle II did from the fifth to eighth encounters including the interest questionnaires for the students. After applying the improvement efforts in cycle II, it has explained before about the students were active, attention and participate in learning process.

The implementation of learning in this cycle has been better when it compared with the cycle I, it is based on the students' activity and interest in learning mathematics. This was suitable the result of students' observation that relates to the learning process, it shows that

an increase from the first cycle to the second cycle while the students' activities which are not in accordance with the learning from the first cycle to the second cycle decreased, thus it can be said that the learning model of experiential learning can improve students' activity during the learning takes place.

The goal of interest in learning mathematics is obtained by the students in cycle II has increased from cycle I, where the result of questionnaire interest in learning in cycle II has increased with average score 4,18 or $84 \%$. So, the interest of student in this research was "good" from the total number of research subjects has reached the criteria of completeness. It relates in accordance with indicators of success in this research increased of average score interest in learning mathematic students both individually and classically about the percentage increased of student activity, because the success indicator in this research has achieved. Then, the researcher as the teacher decided to stop or not continue the learning activities to the next cycle.

\section{CONCLUSION}

Based on the results of research and discussion that has been described in previous chapters, it can be concluded that the interest in learning mathematic through learning model of experiential learning in IX class of students at SMPN 13 Parepare. This is indicated by the increasing of the average value of interest in learning mathematics students in the first cycle was 3.74 or $75 \%$ as the category of "good" to 4.18 or $84 \%$ was in the category of "good" cycle II.

\section{REFERENCES}

[1] Majid, Abdul. Learning Strategies. Bandung: PT Remaja Rosdakarya 2014.

[2] Ershad, Al. Application of Experiential Learning Method In Science Education for Elementary School Students Improve HasBelajar.Indonesian Journal of Physics Education, (Online), 2009 ( http://journal.unnes.ac.id , accessed 24 April 2016).

[3] Djaali. Educational Psychology. Jakarta: Earth Literacy.

[4] Arikunto, Suharsimi., Suhardjono., \& Supardi. 2007. Class Action Research. Jakarta: PT Bumi Aksara 2009.

[5] Silberman, Mel. Experiential Learning. Bandung: Nusa Media 2014.

[6] G. Eason, B. Noble, and I.N. Sneddon, "On certain integrals of LipschitzHankel type involving products of Bessel fu 